\title{
The importance of multi-professional, interdisciplinary care in rehabilitation and health promotion directed at patients with cleft lip/palate
}

\author{
A importância do atendimento multiprofissional e interdisciplinar \\ na reabilitação e promoção de saúde ao portador de \\ fissura labiopalatal
}

\begin{abstract}
Cleft lip/palate is the one of the most prevalent congenital craniofacial deformities. According to data from the Brazilian Institute of Statistics and studies carried out at the Craniofacial Anomaly Rehabilitation Hospital in Bauru/SP, cleft lip/palate occurs in one out of every 650 births in Brazil. Cleft lip/palate may result in impairments that stigmatize the individual and have an impact on health, emotions and social interaction. Treatment requires children with cleft lip/ palate to be monitored from birth to young adulthood in order to avoid further functional, aesthetic and psychological impact. The present literature review offers reflections on the organization of the work process of multi-professional, interdisciplinary care in rehabilitation and health promotion directed at patients with cleft lip/palate. There are gaps in the integration between the specialties that make up the three levels of care in the Brazilian public health care system and there is a need for the government to ensure reference and counter-reference services.
\end{abstract}

Key words: Cleft lip; cleft palate; Public Health; Dentistry

\section{Resumo}

As fissuras labiopalatais constituem um dos defeitos congênitos mais freqüentes da região de cabeça e pescoço. No Brasil, segundo dados do IBGE (Instituto Brasileiro de Geografia e Estatística) e estudos realizados pelo Hospital de Reabilitação de Anomalias Craniofaciais (HRAC) em Bauru/SP, a prevalência ocorre em uma grandeza de 1:650 nascimentos. Resultam em uma série de seqüelas que podem acompanhar o portador durante toda a vida apresentando ônus em termos de morbidade, estigmatização e exclusão social. $\bigcirc$ tratamento requer um acompanhamento contínuo desde o nascimento até a fase final do crescimento com o objetivo de prevenir e tratar transtornos estéticos, funcionais e psico-sociais. Esta revisão da literatura busca refletir sobre a organização do processo de trabalho através de um atendimento multiprofissional e interdisciplinar nas ações de reabilitação e promoção da saúde ao portador de fissura labiopalatal. Há presença de lacunas na integração entre as especialidades que compõem os três níveis de atenção no Sistema Único de Saúde (SUS) e há necessidade de atuação do poder público para que sejam garantidos os serviços de referência e contra-referência.

Palavras-chave: Fissura labiopalatal; Saúde Coletiva; Odontologia

\author{
Daniela Lorenzzoni a \\ Daniela Lemos Carcereri a \\ Arno Locks a
}

a Center for Health Sciences, Postgraduate Program in Dentistry - Public Health, Universidade Federal de Santa Catarina, Florianópolis, SC, Brazil

\author{
Correspondence: \\ Daniela Lorenzzoni \\ Rodovia Joao Paulo, 820, ap. 203 Bloco C \\ Florianópolis, SC - Brazil \\ 88030-300 \\ E-mail: danilorenzzoni@yahoo.com.br
}

Received: May 18, 2009

Accepted: February 2, 2010

Conflict of Interest Statement: The authors state that there are no financial and personal conflicts of interest that could have inappropriately influenced their work.

Copyright: (C) 2010 Lorenzzoni et al.; licensee EDIPUCRS. This is an Open Access article distributed under the terms of the Creative Commons AttributionNoncommercial-No Derivative Works 3.0 Unported License. 


\section{Introduction}

The complex formation of the face and oral cavity occurs in the embryonic phase and involves the development of multiple tissue processes that unite and fuse in an extremely ordered fashion. Abnormalities in the growth process of these tissues or in their fusion may result in the formation of orofacial fissures, commonly known as cleft lip and palate (CLP). The failed fusion of the median nasal process and maxillary process results in a cleft lip, whereas the failed fusion of the palatine processes results in a cleft palate (1). The pathogenesis of this condition begins in the fifth week of gestation (period in which the median nasal processes and maxillary processes fuse) and is only completed in the 12 week of fetal development (2). CLP is one of the most frequent congenital malformations of the head and neck region. Early diagnosis may be performed during prenatal care through an ultrasound exam beginning at 14 weeks of gestation (3). Although described for the first time nearly two centuries ago, the etiology of CLP is not clearly established (4). There is evidence of genetic and environmental factors acting either alone or together in the origin of CLP $(5,6)$. These factors result in a series of conditions that may accompany the individual throughout life, such as aesthetic alterations, functional abnormalities in suckling, swallowing, chewing, breathing, speech and hearing as well as emotional problems (6), all of which have a prolonged, negative influence over health and social integration (7).

Birth is the beginning of a long journey in the search for rehabilitation treatment for patients with CLP. There is a need for both surgical and non-surgical treatment involving various specialties, a multi-professional team and continual, long-term accompaniment of the patient and family in the context of the public health care system (basic health care, specialized centers and hospital).

The need for a surgeon dentist in all stages of treatment demonstrates the special interest on the part of dentistry regarding this anomaly (8). It is possible that the patient's needs are not fully met - whether due to geographical distances from specialized centers or difficulties in the maintenance of treatment, particularly in terms of rehabilitation, or due to a lack of ties between the health care team and services (9).

This paper offers a literature addressing the importance of multi-professional, interdisciplinary care in rehabilitation and health promotion directed at patients with cleft lip/palate.

\section{Cleft Lip and/or Palate}

CLP is estimated to occur in one out of every 600 to 700 births. According to some studies, congenital malformations of the lip and/or palate are between the third and fourth most common forms of congenital malformation (10). Epidemiological studies reveal a greater prevalence of both cleft lip and palate, followed by cleft palate alone and, less frequently, cleft lip alone. There is a higher occurrence cleft palate among the female gender, whereas the male gender is more affected by cleft lip/palate and cleft lip alone (11-13). The female to male proportion of cleft palate is $3: 2$, which may be attributed to the fact that the secondary palate closes sooner in the male embryo $(1,14)$.

Although the majority of cases of CLP occur in an isolated fashion, more than 250 development syndromes are reported to have a possible association with the condition. The cause of non-syndrome-related CLP does not follow any Mendelian inheritance pattern and appears to be heterogeneous. Thus, the proneness toward developing CLP may be related to a greater or lesser number of genes and environmental factors, which, together, may surpass a development threshold (1). Studies on the occurrence of this anomaly in different countries have assessed aspects related to seasonality, social class, ethnic background, age of parents, birth weight, smoking habits, medication intake, residence of origin, pollution, occupation, alcohol intake, drug use, diseases in the mother, exposure to herbicides/pesticides, exposure to radiation and heredity (15). Leite et al. (4) found a greater risk of CLP in children whose mothers had a history of malformation, gynecological infection, epilepsy/convulsions and viruses.

With regard to genetics, the prevalence increases at the following proportions when there is a family history of CLP: normal parents have a $0.1 \%$ chance of having a child with CLP; normal parents with a child with CLP have a $4.5 \%$ chance of having another child with CLP; and families in which one parent and one child has CLP have a $15 \%$ chance of having another child with CLP (16). In terms of social class, a number of studies report that a low socioeconomic level is a risk factor for congenital anomalies and may predispose children to CLP, which is linked to environmental factors (17-19).

The most commonly used classification in Brazil is that formulated by Spina (20), which takes the incisive foramen as reference and the cleft is subdivided into pre-incisive foramen, trans-incisive foramen and post-incisive foramen. The cleft may be either complete or incomplete, depending on the degree of structure impairment. Depending on the side affected, it may be unilateral, bilateral or median.

1. Pre-incisive foramen cleft (located in front of the incisive foramen) is exclusively labial, originating embryonically from the primary palate and may reach the lip and alveolar ridge.

2. Post-incisive foramen cleft (generally median) may be located only in the uvula, primary palate or may involve the secondary palate. These clefts are different from the other groups in that they do not present aesthetic problems (there is no break of peri-oral structures), but only functional disorders (velopharyngeal mechanism), characterized by nasal speech.

3. Trans-incisive foramen cleft is of greater severity and involves anatomical structures originating from the primary and secondary palates. There is a break of the entire length of the maxilla from the lip to the uvula, with ample communication between the oral and nasal cavities.

4. There are also rare clefts that are oblique to the lip, nose or even the entire face. 


\section{Interdisciplinary Rehabilitation}

Birth is the beginning of a long journey in the search for rehabilitation treatment for patients with CLP. Such treatment involves various specialties that make up the three levels of Brazilian public health care with the aim of achieving adequate aesthetic-functional rehabilitation as well as social, psychological and professional integration.

In the mid 1990s, two broad-scoped studies were carried out in North America and Europe on the need for integral, specialized, multi-professional, long-term care for patients with craniofacial anomalies. Different criteria were proposed for the accreditation of health care services that manage these anomalies: composition of multi-professional team; minimal number of procedures/year/specialist and meetings/year/team; discussion and agreement on individual treatment plans; documentation and archival maintenance of clinical data and exams; contact and referral of family members to support groups; and reference/counter-reference articulation $(21,22)$

In Brazil, there is no specific legislation on the composition of the health care team or its organizational model (whether multidisciplinary, interdisciplinary, trans-disciplinary or isolated services). Ordinance SAS/MS n. 62 of the Secretary of Health Care and Ministry of Health establishes that hospitals registered for the execution of integrated procedures for the aesthetic-functional rehabilitation of patients with CLP and bone-integrated dental implants must offer the following specialties: oral-maxillofacial surgery, plastic surgery, dentistry (pediatric dentistry, orthodontics, denture placement, implant placement), otolaryngology, speech/ hearing therapy, psychology, social service, medical clinic, nursing, pediatrics, anesthesia, physiotherapy, nutrition and family care (23).

The Craniofacial Anomaly Rehabilitation Hospital/ Universidade de São Paulo (CARH/USP) in Bauru in the state of São Paulo is the largest reference center in Brazil specialized in the treatment of congenital anomalies of the head and face, with an emphasis on cleft lip and/or palate and hearing disabilities. The patients are from all of Brazil and neighboring countries. CARH-USP is a health care model that involves research, teaching and free health care services (24). Health care in Brazil is also distributed among regional centers for outpatient support in the rehabilitation process, involving medicine, dentistry, speech/hearing therapy, psychology and social services. These centers offer care in both the pre-surgery and post-surgery phases and rely on the participation of municipal authorities and state secretaries, with CARH/USP participating in the training of human resources. There are 12 duly-registered regional centers in Brazil, distributed in different regions. There are also sub-centers, which are outpatient care units maintained by the Foundation for the Study and Treatment of Craniofacial Deformities, which is a partner organization of CARH/USP. Three such unites have been implanted in Brazil: one in Campo Grande/MS, one in Itararé/SP and one in metropolitan Sao Paulo/SP (25).
According to Silva et al. (26), patients with special needs, such as those with CLP, require specific care in accordance with the actual needs of the patient. This involves clinical procedures for the rehabilitation of oral health as well as issues beyond the specific knowledge of the field of dentistry. The starting point for rehabilitation is the family. Before the child undergoes basic treatment, the family needs contact with the entire health care team (basic care, specialized centers and hospital), which should offer the necessary support to develop the emotional stability lost with the impact of the birth of the child with CLP (27).

Treatment involves a team formed by different specialists, who should work in an integrated fashion with the aim of giving the patient the best possible treatment (25). A series of surgeries are needed to correct the deformity in terms of both aesthetics (lip, nose, face) and function (palate), which begins with primary surgeries (cheiloplasty and palatoplasty). Cheiloplasty (corrective lip surgery) is performed when the child is about three months of age or reaches a body weight of five kilos. Cheiloplasty is performed in a single session in cases of unilateral cleft and in two sessions in cases of bilateral cleft (at 3 and 6 months of age). Palatoplasty (corrective palate surgery) is performed at about 12 months of age and secondary palate surgery is commonly performed at this time when primary surgery is unsuccessful, which is a common occurrence (6).

The aim of dentistry is to promote health, diagnose and treat existing lesions, recuperate teeth through restorations and replace missing teeth in the dental arches. This involves the following specialties: periodontology, pediatric dentistry, prosthetics, endodontics, implant dentistry, oral-maxillofacial surgery, orthodontics and general dentistry. For complete patient rehabilitation, the prevention of oral conditions, such as dental caries and periodontal disease, is fundamental, as patients with CLP have an increased risk of developing such conditions $(19,28)$.

According to Faustino Silva (29), parents/guardians have inadequate knowledge regarding oral health care in early childhood. It is therefore necessary to prioritize educative actions directed at primary health care, as families have a significant impact on the development of oral health habits in children within different socio-cultural contexts.

There is an influence from other biological factors, such as congenitally missing teeth and/or supernumerary teeth (30). Different malocclusions and dental anomalies may occur with CLP (31), such as an atypical positioning of the teeth and the presence of cicatricial fibrosis in the area of surgical repair and the cleft itself. These factors hamper hygiene and create an environment that is favorable to the development of infection and disease in oral tissues, such as caries and gingival alterations (12,32-34). Compromised oral tissues whether due to dental caries or periodontal disease - affect the patient considerably. The first implication is with regard to surgery, which should be performed with adequate oral conditions in order to avoid contamination of area being operated. Contamination has a negative effect on the postoperative recovery period and could lead to early teeth 
loss, thereby further hindering treatment and complicating the prognosis (35).

Between nine and 12 years of age, a secondary bone graft is performed in the area affected by the cleft (employed at CARH-USP in Bauru, as a primary bone graft is believed to affect facial growth). The aim of this procedure is to offer support to the teeth that will be moved during orthodontic treatment and in cases in which there is a need for dental implants (6). Orthodontic treatment is performed after the conclusion of facial growth. "Orthodontic intervention should be an integral part of the overall treatment plan for the patient, in which surgery and prosthetics are also concomitantly considered" (35).

Nutritional accompaniment should be encouraged, as patients with CLP have difficulty feeding, especially when the family has not received orientation. The most common problems are inadequate suction due to a lack of intra-oral pressure, prolonged breastfeeding time and regurgitation. Early counseling regarding the best feeding techniques leads to well-oriented families, the children of which are fed more easily and grow more; there is also less anxiety on the part of the parents. Breastfeeding is possible for infants with CLP and should be encouraged, provided the child can suckle and the mother feels comfortable breastfeeding. Although more laborious than bottle feeding, breastfeeding is recommended due to the nutritive value and antibacterial properties of mother's milk. This assists in the prevention of infection, especially ear infection, which is common among children with CLP (36).

As many patients have insufficient weight gain, proper counseling is fundamental to enabling primary surgery. The infant needs to have a body weight of five $\mathrm{Kg}$ prior to surgery. For such, nutrition is often composed of a highcalorie standard diet with high sugar intake. There is also a high intake of citric fruit juices to combat anemia (37), which contributes to a drop in $\mathrm{pH}$ in the oral cavity and favors the demineralization of the teeth, making the oral environment propitious to the development of dental caries (38).

Individuals with CLP run the risk of problems with speech, resonance and hearing as well as impaired aesthetics. In the pre-surgery period, the speech/hearing therapist gives the parents orientation. In the post-surgery period, the therapist works with the patient to correct articulation problems and adjust the voice. The aim of early treatment is to help in sensory stimuli, especially in the anterior portion of oral cavity in order to avoid the establishment of compensatory movements that may affect speech acquisition. Accentuated nasal resonance is a common alteration in patients with CLP, but can be minimized or even avoided if the cleft is closed in time - generally by two years of age (29). Physiotherapy is performed following corrective and aesthetic surgeries, with massage and facial mimicking exercises, which assist in the healing process, lip mobility and local irrigation.

Psychology plays a fundamental role in the complete rehabilitation of patients with CLP by providing necessary support so that both patient and family can overcome the trauma stemming from aesthetic and functional problems.
The psychologist works with parents and family to attenuate the anxiety that naturally arises from the perception of the problem upon the birth of the child. According to Viana et al. (39), the birth of a child with malformation causes a family crisis due to the medical difficulties that need to be faced and the fact that the infant does not correspond to the expectations of health and perfection on the part of the parents and society as a whole.

The aesthetic and phonetic alterations generally cause other problems of a psychosocial nature, such as isolation and scholastic and/or economic difficulties, causing patients with CLP serious social maladjustments. Social services work with the patient and family in a dynamic fashion, offering adequate technical support for a community life within the patterns of normality. Genetic counseling may also be employed to orientate the patient and family with regard to the medical aspects of the condition, including the risk of recurrence, prenatal diagnosis, complications, indication of support groups, therapy and prognosis (30).

\section{Discussion}

As CLP is a highly prevalent anomaly that is difficult to prevent, early access to care and continued follow up of both patient and family are of fundamental importance. While there is recognition of the health care services and specialties that should make up the rehabilitation system, there are a number of questions regarding the health care model (as reflected in the work process of the health professionals) and the functioning of the referral system, which need to be considered in order to give the support necessary during the rehabilitation process.

According to Monlleó; Lopes (9), reference centers for patients with CLP are more concentrated in the southern and southeastern regions of Brazil. Thus, geographical distance is a problem for much of this population. Moreover, treatment is costly and prolonged and the majority of the population has a low socioeconomic status.

There is fragility in the work process and the organization of the referral system. The reference and counter-reference mechanisms operate through formal and informal means, but with no guaranty of access to the services required on the three levels of health care. Ordination and hierarchization problems in the system and inequality in access to the services make care out of the reach of many patients and their families. The work process reveals a practice centered on curative/care measures, in which fragmentation of treatment occurs, restricted to care offered by specialties and basic care is only performed in isolated events (40).

According to Narvai (41), certain equipment and specialists are not needed in all places. However, all patients should have access to equipment and specialists whenever needed. In order to ensure patients access to the resources they require, the establishment of reference and counter-reference mechanisms is fundamental. For such, patients are sent from one health care sector to another (reference), generally on different levels of care; once the service is performed, the 
patient is send back to the health sector of origin (counterreference).

In Brazil, the health care model is organized in hierarchical levels of increasing complexity, forming as pyramid structure. According to Mendes (42), this is a strongly hegemonic, fragmented health care system that is (dis)organized in a set of isolated points of health care, with weak primary health care that is unable to offer continued care to individuals or a particular population.

Due to the complexity of treating patients with CLP, there is the involvement of multiple specialties and patients are transferred between specialties through referrals with no guaranty that the treatment will be carried out within the established timeframe. Inter-professional contact and a concern for considering the individual in his/her integrality are quite restricted in this health care structuring model (43).

In order to offer integral care with an inter-disciplinary team, it is essential for actions to be harmonized in the team, with the exchange of experiences and knowledge between the disciplines involved in order to provide a complete rehabilitation process (44). As the body is not the sum of its anatomical parts and health is at the same time social, biological and psychological (45), integrality is a value to be defended in the practices of health care professionals. This is expressed in the form in which professionals respond to patients and also depends on how health care services are organized (46).

Regarding geographical distances from specialized centers, effective communication with basic health care professionals (through Basic Health Units) should be established, as these individuals are closer to the patients and are responsible for family support and follow up as well as communication and integration with specialized centers and hospitals. This would enable treatment with integral, humanized care.

\section{Conclusion}

Rehabilitation treatment for patients with CLP is complex and involves a multi-professional team, which should operate within an interdisciplinary work process. The structuring of services in the Brazilian health care system is fundamental in order to ensure effective communication between health professionals on all levels of health care. These professionals need to know how to interact with this population, offering care, clarifications and necessary referrals, which are fundamental to the construction of a health promotion paradigm. There is a need for the government to ensure services and provide humanized, resolutive care of better quality by demanding a commitment on the part of all professionals regarding the integration of these individuals to society.

\section{References}

1. Neville BW. Defeitos do desenvolvimento da região maxilofacial e oral. In: Nevillle BW. Patologia oral e maxilofacial. $2^{a}$ ed. Rio de Janeiro: Guanabara Koogan; 2004. p.2-47.

2. Moore KL, Persaud TVN. Embriologia clínica. Rio de Janeiro: Elsevier; 2004

3. Gorlin RJ, Cohen Jr MM, Hennekan RCM. Orofacial clefting syndromes. In: Gorlin RJ, Cohen Jr MM, Hennekan RCM. Syndromes of the head and neck. $4^{a}$ ed. Oxford: Oxford University Press; 2001. p.850-60.

4. Leite ICG, Paumgartten FJR, Koifman S. Fendas orofaciais no recémnascido e o uso de medicamentos e condições de saúde materna: estudo caso-controle na cidade do Rio de Janeiro. Rev Bras Saúde Mater Infant 2005;5:35-43.

5. Baroneza JE, Faria MJSS, Kuasne, H, Carneiro JLV, Oliveira JC. Dados epidemiológicos de portadores de fissuras labiopalatinas de uma instituição especializada de Londrina, Estado do Paraná. Acta Sci Health Sci 2005;27:31-5.

6. Capelozza Filho L, Silva Filho OG. Fissuras lábio-palatais. In: Petrelli E, coordenador. Ortodontia para fonoaudiologia. Curitiba: Lovise; 1992. p. 195-239.

7. Word Health Organization - Who. Global strategies to reduce the health-care burden of craniofacial anomalies. Geneva: Word Health Organization; 2002.

8. Froes Filho RR. Tratamento de pacientes portadores de fissuras labiopalatais. Rev. Associação Odontológica do Norte do Paraná; 2003; 17:26-7.

9. Monlleó IL, Lopes VLGS. Anomalias craniofaciais: descrição e avaliação das características gerais da atenção no Sistema Único de Saúde. Cad Saúde Pública 2006;22:913-22.
10. Nagem Filho H, Moraes N, Rocha RGF da. Contribuição para $\odot$ estudo da prevalência das más formações congênita lábio-palatais na população escolar de Bauru. Rev Fac Odont 1968;6:1 11-28.

11. Lima PT. Fissuras congênitas da face e do crânio. In: Mustacchi Z, Peres S. Genética baseada em evidências: síndromes e heranças. São Paulo:CID; 2000. p.687-99.

12. Silva HA, Bordon AKCB, Duarte DA. Estudo da fissura labiopalatal: aspectos clínicos desta malformação e suas repercussões. J Bras Fonoaudiol 2003;4:71-4

13. Freitas JAS, Dalben Gda S, Santamaria M Jr, Freitas PZ. Current data on the characterization of oral clefts in Brazil. Braz Oral Res 2004; 18:128-33

14. França CMC, Locks A. Incidência das fissuras labiopalatinas de crianças nascidas na cidade de Joinville (SC) no período de 1994. 2000. J Bras Ortodon Ortop Facial 2003;8:429-36.

15. Loffredo LCM, Freitas JAS, Grigolli AAG. Prevalência de fissuras orais de 1975 a 1994. Rev Saúde Pública 2001;35:571-75

16. Gonzaga HFS. Malformações da face de interesse para o pediatra. Pediatria Atual 2001;14:53-8.

17. Vrijheid H, Dolk H, Stone D, Abramsky L, Alberman E, Scott JE. Socioeconomic inequalities in risk of congenital anomaly. Arch Dis Child 2000;82:349-52

18. Cerqueira MN, Teixeira SC, Naressi SCM, Ferreira APP. Ocorrência de fissuras labiopalatais na cidade de São José dos Campos - SP Rev Bras Epidemiol 2005;8:161-6.

19. Silva CM. Avaliação das condições bucais de pacientes com fissura labiopalatal participantes de um programa de manutenção de saúde bucal [dissertação]. Florianópolis (SC): Universidade Federa de Santa Catarina; 2006. 
20. Spina V, Psillakis JM, Lapa FS. Classificação das fissuras labiopalatinas: sugestão de modificação. Rev Hosp Clín Fac Med São Paulo 1972;27:5-6.

21. Strauss PR. Cleft palate and craniofacial teams in the United States and Canada: a national survey of team organization and standards of care. Cleft Palate Craniofac J. 1998;35:473-80.

22. Shaw WC, Semb G, Nelson P, Brattström V, Mølsted K, PrahlAndersen B, Gundlach KK. The Eurocleft Project 1996-2000: overview. J Craniomaxillofac Surg 2001;29:131-40.

23. Brasil. Ministério da Saúde. Portaria SAS/MS n. 62, 19 de abril de 1994. Normaliza cadastramento de hospitais que realizem procedimentos integrados para reabilitação estético-funcional dos portadores de má-formação lábio-palatal para o Sistema Unnico de Saúde. Diário Oficial da União 1994;3.

24. Freitas JAS. Ciência e humanismo a favor da reabilitação e do próximo. Módulo 30 In: Curso de anomalias congênitas labiopalatais. São Paulo: HRAC/USP; 2006.

25. Graciano MIG, Tavano LDA, Bachega MI. Aspectos psicossociais da reabilitação. In: Trindade IEK, Silva Flho OG. da. Fissuras labiopalatinas: uma abordagem interdisciplinar. São Paulo: Santos; 2007. p.311-33.

26. Silva ZCM da, Pagnoncelli SD, Weber JBB, Fritscher AMG. Avaliação do perfil dos pacientes com necessidades especiais da clínica de odontopediatria da faculdade de odontologia da PUCRS. Rev Odonto Ciênc 2005;20:313-8.

27. Silva OG, Freitas JAS, Okada T. Fissuras labiopalatais: diagnóstico e uma filosofia interdisciplinar de tratamento. In: Pinto VG. Saúde bucal coletiva. $4^{a}$ ed. São Paulo: Santos; 2000. 541 p.

28. Tomita NE, Costa B, Gomide MR, Santos CF, Palma RG. Cárie em portadores de fissuras lábio-palatais: avaliação de dois métodos de diagnóstico. Rev Odontol Univ São Paulo 1996;10:145-51.

29. Faustino-Silva DD, Demétrio D, Fernando R, Nascimento IM, Fontanive PVN, Persici S, Rossoni E. Cuidados em saúde bucal na primeira infância: percepções e conhecimentos de pais ou responsáveis de crianças em um centro de saúde de Porto Alegre RS. Rev Odonto Ciênc 2008;23:375-9.

30. Ribeiro EM, Moreira ASCG. Atualização sobre o tratamento multidisciplinar das fissuras labiais e palatais. RBPS 2005; 18: $31-41$.

31. Jones MC. Etiology of facial clefts: prospective evaluation of 428 patients. Cleft Palate J 1988;25:16-20.

32. Vilela ACS, Sacramento EP, Gomide MR. Educação dos pais versus saúde bucal de bebês fissurados. Revista da APCD 1996; 50 : 357-60.
33. Alves LMLH, Melo GG, Pereira JRD, Cardoso MSO. Prevalência de cárie em portadores de fissura lábio-palatais atendidos no Instituto Materno Infantil de Pernambuco. Odontol Clín Cient 2004;3: 57-60.

34. Lages BEM, Marcos B, Pordeus IA. Saúde bucal em portadores de fissura lábio-palatal: revisão. Revi CROMG 2000;6:88-93.

35. Rocha R, Telles CS. O problema das fissuras labiopalatais: diagnóstico e aspectos clínicos. Rev Soc Bras Ortondontia 1990;1:178-92.

36. Araruna RC, Vendrúscolo DMS. Alimentação da criança com fissura de lábio e/ou palato: um estudo bibliográfico. Rev Latinoam Enfermagem 2000;8:99-105.

37. Dalben G, Costa B, Gomide MR. Características básicas do bebê portador de fissura labiopalatal: aspectos de interesse para $\circ \mathrm{CD}$. Revista da APCD 2002;36:223-6.

38. Dalben GS, Costa B, Gomide MR, Teixeira das Neves LT. Breastfeeding and sugar intake in babies with cleft lip and palate. Cleft Palate J 2003;40:84-7.

39. Viana ML, Giacomoni GH, Rashid L. "O que fiz por merecer?": aspectos psicológicos da relação mãe-filho malformado. Rev Odonto Ciênc 1994;9:21-9.

40. Lorenzzoni D. Avaliação do sistema de referência e contra-referência na atenção à saúde bucal ao portador de fissura de lábio e/ou palato no Estado de Santa Catarina [dissertation]. Florianópolis (SC): Universidade Federal de Santa Catarina; 2007. $142 f$.

41. Narvai PC. Integralidade na atenção básica a saúde. Integralidade? Atenção? Básica? In: Garcia DV, organizador. Novos rumos da saúde bucal: os caminhos da integralidade. Rio de Janeiro: ABORJ/ ANS/UNESCO; 2005. p.28-2.

42. Mendes EV. Atenção Primária a saúde no SUS. Fortaleza: Escola de Saúde Pública do Ceará; 2002. 92p.

43. Campos DWS, Domitti AC. Apoio matricial e equipe de referência: uma metodologia para gestão do trabalho interdisciplinar em saúde. Cad Saúde Pública 2007;23:399-407.

44. Brasil. Ministério da Saúde. Núcleo técnico da Política Nacional de Humanização. HumanizaSUS. Equipe de referência e apoio matricial. Brasília (DF); 2004. 15p.

45. Da Ros MA. Políticas públicas de saúde no Brasil. In: Bagrichevsky $\mathrm{M}$ et al. A saúde em debate na educação física. v. 2, Blumenau: Nova Letra; 2006.

46. Mattos RA. Os sentidos da integralidade: algumas reflexões acerca de valores que merecem ser defendidos. In: Pinheiro R, Mattos RA. Os sentidos da integralidade na atenção e no cuidado à saúde. $6^{a}$ ed. Rio de Janeiro: IMS/UERJ-CEPESC-ABRASCO; 2006. 180p. 